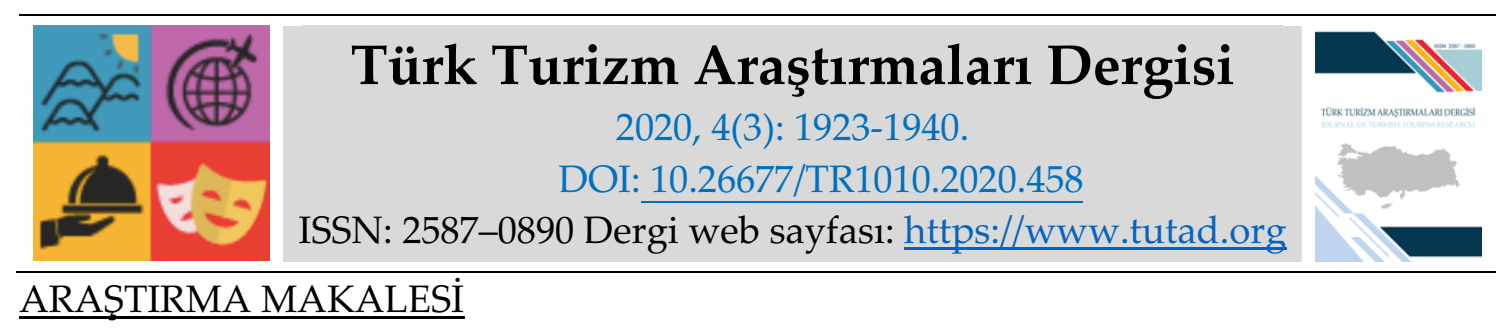

\title{
Otel Çalışanlarının İş-Aile Yaşam Çatışmalarının Yordayıcıları Olarak, İş - Yaşam Doyumu, İş Stresi ve Algılanan Sosyal Destek
}

Dr. Öğretim Üyesi Gözde KARABACAK, Nişantaşı Üniversitesi, İktisadi İdari ve Sosyal Bilimler Fakültesi, İstanbul, e-posta: bilgingozde@hotmail.com

ORCID: https://orcid.org/0000-0001-6206-5166

Prof. Dr. Hacer HARLAK Adnan Menderes Üniversitesi, Fen Edebiyat Fakültesi, Aydın, e-posta: hharlak@adu.edu.tr

ORCID: https://orcid.org/0000-0002-9121-3532

Öz

Son çalışmalar, iş-aile yaşam çatışmasının çalışanlarda yüksek stres, düşük iş ve yaşam doyumu ile sonuçlandığını; algılanan sosyal destek ile hem doyum hem de çatışma düzeyleri arasında ilişki olduğunu göstermiştir. Çalışmanın amacı, söz konusu değişkenler arasındaki ilişkileri ve iş stresinin, algılanan sosyal desteğin ve iş-yaşam doyumunun iş-aile yaşam çatışmasına etkilerini incelemektir. Çalışma, Kuşadası ve İstanbul'daki 5 yıldızlı 316 otel çalışanı ile gerçekleştirilmiştir. Doğrulayıcı faktör, Pearson korelasyon, basit doğrusal regresyon ve Sobel aracılık analizleri kullanılmış, iş stresi ve çatışma değişkenleri arasında anlamlı pozitif, çatışma değişkenleri ile hem sosyal destek hem de doyum ölçümleri arasında negatif ilişkiler bulunmuştur. İş-aile/aile-iş çatışması ve iş doyumu arasında iş stresinin, iş-aile/aile-iş çatışması ve yaşam doyumu arasında iş doyumunun, aile-iş çatışması ve yaşam doyumu arasında ise sosyal desteğin kısmı aracılık etkisi bulunmuştur. Aile ilişkilerinde yaşanan sorunlar ve iş-yaşam doyum düzeylerinin düşük olması, işgörenlerin iş-aile yaşam çatışması düzeyini arttırmaktadır. Yüksek düzeyde iş-aile çatışması ve iş stresi ise aile-iş çatışmasına sebep olmaktadır.

Anahtar Kelimeler: İş-Aile Yaşam Çatışması, İş Doyumu, İş Stresi, Yaşam Doyumu, Algılanan Sosyal Destek.

Makale Gönderme Tarihi: 31.02 .2020

Makale Kabul Tarihi: 03.07.2020

\footnotetext{
Önerilen Atıf:

Karabacak, G. ve Harlak, H. (2020). Otel Çalışanlarının İş-Aile Yaşam Çatışmalarının Yordayıcıları Olarak, İş - Yaşam Doyumu, İş Stresi ve Algılanan Sosyal Destek, Türk Turizm Araştırmaları Dergisi, 4(3): 1923-1940.

(C) 2020 Türk Turizm Araştırmaları Dergisi.
} 


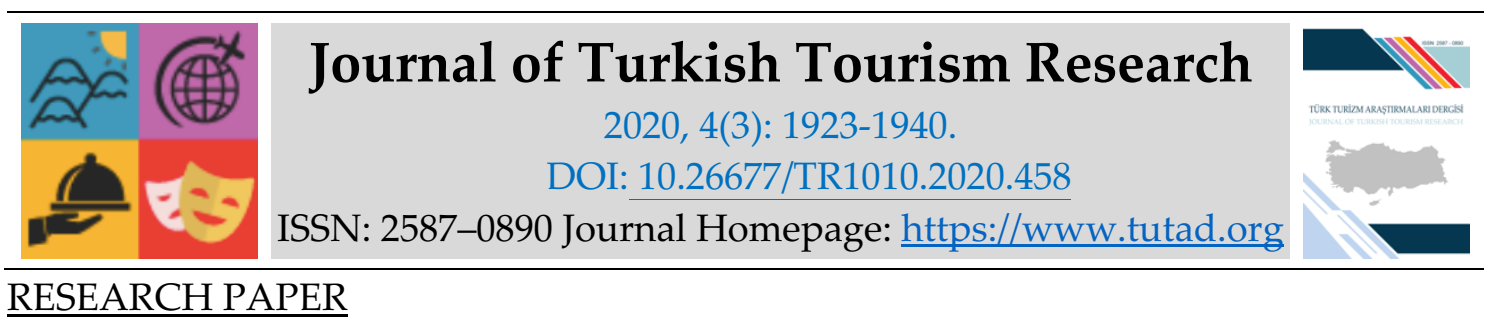

\title{
Job and Life Satisfaction, Work Stress and Perceived Social Support as Predictors of Hotel Employees' Work-Family Life Conflicts
}

Assistant Prof. Dr. Gözde KARABACAK, Nişantaşı University, Faculty of Economics, Administrative and Social Sciences, İstanbul, e-mail: bilgingozde@hotmail.com

ORCID: https://orcid.org/0000-0001-6206-5166

Prof. Dr. Hacer HARLAK, Adnan Menderes University, Faculty of Science and Letters, Aydın, email: hharlak@adu.edu.tr

ORCID: https://orcid.org/0000-0002-9121-3532

\begin{abstract}
Recent studies reveal that the work and family life conflicts result in high levels of stress and in low levels of job and life satisfaction in employees. Also, they showed that there are correlations between perceived social support and both the intensity of conflicts and the levels of satisfaction. The aims of present study were to investigate the correlations between these variables, and the impacts of work stress, perceived social support and job and life satisfaction on work-family life conflicts. The study was conducted by surveying 316 hotel employees who were employed at the various departments of five-star hotels in Kuşadası and İstanbul. Pearson correlation analyses and simple linear regression analyses were used for statistical testing. A significant positive correlation was found between conflict variables and work stress however; negative correlations were obtained between conflict variables and both social support and satisfaction measures. A series of linear regression analyses revealed that family-work conflict, job and life satisfaction were the significant predictors of work-family conflict and, work-family conflict and work stress were the significant as predictors of family-work conflict. Problematic family conflicts and lowlevel work- life satisfaction have increased the work-family conflicts. The high-level work-family conflict and work stress also cause a family-work conflict.
\end{abstract}

Keywords: Work-Family Life Conflict, Job Satisfaction, Work Stress, Life Satisfaction, Perceived Social Support.

Received: 31.02 .2020

Accepted: 03.07.2020

Suggested Citation:

Karabacak, G. and Harlak, H. (2020). Job and Life Satisfaction, Work Stress and Perceived Social Support As Predictors of Hotel Employees' Work-Family Life Conflicts, Journal of Turkish Tourism Research, 4(3): 1923-1940.

(c) 2020 Türk Turizm Araştırmaları Dergisi. 


\section{Gíriş}

Çalışanların doyum düzeyleri ve psikolojik durumları, turizmde müşteri memnuniyetini ve hizmet kalitesini doğrudan etkilemektedir. Emek yoğun bir sektör olan turizmde, uzun çalışma saatleri, iş belirsizliği ve stresli çalışma ortamı gibi sorunlar çalışanların iş doyumunu azaltırken; hafta sonları ve özel günlerde işlerin yoğun olması, çalışanların özel yaşamına ve aile hayatına ayıracakları süre ve enerjiyi sınırlamaktadır.

Yakın bir geçmişe dayanan iş ve aile yaşamının ayrı alanlar olduğu düşüncesi, günümüzde bu iki yaşam alanı arasındaki yayılma (Higgins ve Duxbury, 1992; Ilies, Wilson ve Wagner, 2009) ya da geçiş etkisine (Baker, Demerouti ve Dollard, 2008) yerini bırakmıştır. Yaşam alanları arasındaki bu etkiler, aktarılan negatif ya da pozitif deneyimler üzerindendir. Zorlu yaşam ve çalışma koşulları aynı anda her iki yaşam alanından da başarı ve doyum sağlamanın güç olduğunu, bir alana verilen emek ve ayrılan zaman arttıkça diğer alanın ihmal edilebileceğine yönelik göstergelerdir. Dolayısıyla toplumsal normlarla çelişen çift gelirli-çift kariyerli günümüz yeni aile yapısında, aile ve iş yaşamına ait üstlenilen rollerin eş zamanlı talepleri, bireylerin ikilemde kalıp çatışma yaşamasına neden olabilmekte, yaşanan bu çatışma bireylerin iş ve yaşam doyumlarını olumsuz yönde etkileyebilmektedir. Birey söz konusu gereklilikler nedeniyle bir yandan kendini baskı altında hissetmekte diğer yandan önceliklerini belirleme konusunda rolleri arasında çatışma yaşamaktadır. Böyle bir durumda, sosyal destek alınması bireyin iş-aile yaşam dengesinin kurulmasına katkıda bulunarak, iş-aile yaşam çatışmalarını ve iş stresini azaltabilmektedir. Aksi takdirde yaşanan bu rol çatışmaları iş-aile çatışması odaklı ise, fiziksel/psikolojik sağlığın bozulması (Frone, Russell ve Cooper, 1997), ebeveynlik/evlilik/genel yaşam doyumunda azalma (Polatçı, 2015), vb., aile-iş çatışması odaklı ise iş doyumunda azalma, işe geç kalma, işten ayrılma niyeti, performans ve motivasyon düşüklügü gibi örgütsel sonuçlar doğurmaktadır (Odle-Dusseau, Britt ve Bobko, 2011).

Neticede iş-aile, aile-iş çatı̧̧ması, iş doyumu, yaşam doyumu, iş stresi ve algılanan sosyal destek, kavramlarının birbirleri ile etkileşim içinde olduğu görülmektedir. İşgücünün öneminin sürekli vurgulandığı emek-yoğun turizm sektöründe faaliyet gösteren otel işletmeleri çalışanlarının söz konusu değişkenler yönünden incelenmesi, daha etkin ve verimli çalışma koşullarının sağlanması, iş ve yaşam doyumunun nasıl yükseltilebileceği ve olası durumlarda iş-aile yaşam çatışmasının nasıl etkin yönetilebileceği konusunda yol gösterecek olması bakımından önemli ve gereklidir. Bu çerçevede çalışmada ele alınan kavramların bağlantıları incelenerek, işletme yönetimi ve politikaları açısından uygulamaya dair bazı öngörülerin oluşturulması hedeflenmiştir.

\section{KURAMSAL ÇERÇEVE}

İş-aile yaşam çatışması (İAYÇ) araştırmaları, Kahn ve arkadaşlarının (1964) iş stresinin temel nedeni olan roller arası çatışmayı tanımlamalarıyla başlamış (Öcal, 2008; Diker, 2010), çift kariyerli, çift gelirli ailelerin artışıyla her geçen gün daha da önem kazanmıştır (Casper vd., 2011). İAYÇ, temelde sosyal bir rolün, diğer bir sosyal rolü engellemesi olduğundan, bireyin aile yaşamı iş yaşamını olumsuz etkileyebileceği gibi, iş yaşamı da aile yaşamını olumsuz etkileyebilir. Dolayısıyla İAYÇ, "iş-aile çatışması (İAÇ)" ve "aile-iş çatışması (AİÇ)" olmak üzere iki yönlüdür. Bireyin ailevi rolleri, iş ile ilgili rollerini yerine getirmesini engelliyorsa AİÇ; iş rollerinin gereklilikleri aile rollerini engelliyorsa İAÇ yaşanmaktadır (Byron, 2005). Bireyler, çatışmalardan sadece birini ya da eş zamanlı her ikisini de yaşayabilmektedirler (Öcal, 2008). Gutek, Searle ve Klepa (1991), bireylerin bu çift yönü çatışma türünden aile-iş çatışmasını daha az algıladıklarını belirtirken, nedenini; ev işlerinin daha esnek olması, bireylerin ev yaşamları üzerinde daha fazla 
kontrol sahibi olması ve işle ilgili sorumlulukların ailevi sorumluluklarından daha kolay belirlenebilir nitelikte olmasına dayandırmaktadırlar.

Yaşam kavramı bu çalışmada, "iş ve iş dışı alanların toplamı" olarak formüle edilmiştir. Bu doğrultuda, bireyin iş dışı yaşamı ile ilgili genel duygusal tepkisi ya da hayata yönelik tutumu "yaşam doyumu" (Özdevecioğlu ve Doruk, 2009); işini değerlendirmesinden kaynaklanan pozitif duygusal durumu "iş doyumu" olarak tanımlanmaktadır (Wilkin, 2012). Bireyler zamanlarının çoğunu iş ortamında geçirmekte ve iş rollerini, eksiksiz ve en iyi şekilde yerine getirmeye dair beklentilere cevap vermeye çalışmaktadırlar. Bu beklentiler, çalışma ortamında bireyi gerilimli hale getirebilmektedir. Bu durumla ilgili olarak modern çağın sorunu olan "iş stresi" kavramı ortaya çıkmıştır. İş stresi, çalışanın sadece iş yaşamını değil, çeşitli kuramlarda da açıklandığı gibi, aile yaşamını da etkileyebilmektedir.

İş stresi tartışmaları Kurt Lewin'nin "Alan Kuramı" ve "Davranış" tanımına dayanan (Erdem, Aslan ve Sarı̈üzel, 2009) sosyal destek kavramı üzerinde durulmaktadır. Sosyal destek, bireyleri stresin etkilerinden korumaya yönelik sosyal etkileşimler ve kişilerarası iletişimleri kapsar (Aycan ve Eskin, 2005). Bu tür destekler gerek günlük yaşamda gerekse kriz ve ihtiyaç anlarında, stresin olumsuz etkilerini azaltabilmektedir (Sayılan ve Boğa, 2018).

Çatışma ve doyum değişkenleri açısından ilgili yazın tarandığında, İAYÇ'nin hem iş doyumu ile doğrudan ilişkili olduğu hem de bu ilişkiye bazı değişkenlerin aracılık ettiğine dair araştırma bulgularının varlığı dikkati çekmektedir. Adams vd., (1996), İAYÇ'nin iş doyumu üzerinde doğrudan etkili olduğunu belirtirken, Netemeyer vd., (2004), İAÇ ile iş doyumu arasındaki ilişkiye iş stresinin; AİÇ ile iş doyumu arasındaki ilişkiye ise iş stresi ve performansın ayrı ayrı aracılık ettiğini vurgulamaktadır. Öte yandan Grandey ve Cropanzano (2005), çalışanların İAÇ düzeylerinin iş doyumu düzeyleri ile negatif ilişkili olduğunu, AIÇ̧'nin ise iş doyumu ile bir ilişkisinin bulunmadığını bildirmektedir. İAYÇ ile yaşam doyumu ilişkisinin negatif olduğu sonucuna varan çalışmaların (Karabay, 2015; Taşdelen-Karçkay ve Bakalım 2017) yanı sıra, bu değişkenler arasında ilişki bulunmadığını gösteren çalışmalar da vardır (Üzümcü ve Akpulat, 2017). Özetle, mevcut çalışmalar çatışma ve doyum değişkenleri arasındaki ilişkinin doğası konusunda farklı yönde bulgular ortaya koymuştur.

Öte yandan literatürde AİYÇ ile stres arasındaki ilişki de tartışılmıştır. Efeoğlu ve Özgen'in (2007) İAYÇ çatışması ile iş stresi ilişkisini incelediği çalışmanda, iş-aile çatışmasının iş stresi ile pozitif yönde ilişkili olduğu, AIÇ’nin ise, iş stresi ile ilişkili olmadığı bulunmuştur. Başka bir çalışmada (Erdem, Aslan ve Sarıüzel, 2009), iş stresi arttıkça AIÇ’nin arttığı, dolayısıyla AİÇ'deki değişimin iş stresi ile açılanmasının mümkün olabileceği belirtilmiştir. Öztürk'ün (2008) çalışma bulguları, İAÇ'nin, iş stresindeki varyansın beşte birinden fazlasını açıkladığını, Karatepe ve Baddar (2006) ise çalışanların İAÇ düzeylerinin iş stresi düzeyleri üzerinde etkili olduğunu, ancak AIÇ’nin iş stresi üzerinde anlamlı bir etkisinin olmadığını göstermiştir. Karakaş ve Şahin'in (2017) araştırma sonuçları, iş-aile çatışması ile iş stresi arasında orta düzeyde olumlu bir ilişki bulunduğunu göstermiştir. Genel olarak bu sonuçlar, özellikle İAÇ arttıkça iş stresinin de arttığını tutarlı bir şekilde ortaya koymaktadır.

İşs stresi ve iş doyumu ilişkisinin incelendiği çalışma sonuçları, bu iki değişkenin negatif yönde ilişkili olduğu konusunda görüş birliği içerisindedir (İsmail vd., 2009; Karabay, 2015; Tekingündüz vd., 2015). Araştırmalarda yaşam doyumunun çoğunlukla genel stres düzeyiyle ilişkisi incelenmiştir. Yaşam doyumu ile iş stresi ilişkisinin ele alındığı bir çalışmada bulgular, iki değişken arasında negatif yönde bir ilişkiye işaret etmektedir (Çiftçi ve Güner, 2018). Polatçı 
(2015) ise yaşam doyumu ile algılanan sosyal destek arasında anlamlı pozitif ilişki bulmuştur. Sonuç olarak ilgili literatürde bazı çelişkili bulgular bulunmakla birlikte bu çalışmada ele alınan tüm kavramların birbirleriyle karşılıklı ilişkili olduğu görülmektedir. Buna göre, iş-aile yaşam çatışması arttıkça iş stresi artmakta, iş ve yaşam doyumu azalmaktadır. Algılanan sosyal destek artıkça iş stresi azalmakta, buna karşılık yaşam doyumu artmaktadır.

$\mathrm{Bu}$ çalışmada ele alınan değişkenlerin birbiriyle karşılıklı ilişkileri yerine daha çok tümünün birbiriyle ilişkilerinin nasıl bir örüntü oluşturduğuna odaklanılmış ve özellikle İAÇ ile AİÇ'nin iş stresi ve algilanan sosyal desteğin iş ve yaşam doyumu üzerindeki etkilerinin incelenmesi amaçlanmıştır. Çalışma kendine özgü İAYÇ ve stres koşulları bulunan otel işletmelerinin çalışanları ile yürütülmüştür.

\section{YÖNTEM}

\section{Örneklem ${ }^{1}$}

Araştırma örneklemini, İstanbul (206 kişi) ve Kuşadası'ndaki (110 kişi) 5 yıldızlı otellerin çeşitli departmanlarında çalışan toplam 316 personel oluşturmuştur. 5 yıldızlı otellerin tercih edilmesinde, alan yazındaki genellikle büyük işletmelerde çalışan bireylerin daha fazla İAÇ ve iş stresi yaşadıkları, doyum düzeylerinin ise küçük işletmelerde çalışanlara oranla daha az olduğuna ilişkin bulgular (Efeoğlu 2006) belirleyici olmuştur. Örnekleme dahil edilmede, departman ve statü farklılığı göz edilmemiş, katılımcıların T.C. vatandaşı olması ve 18 yaşını tamamlamış olması ölçütüne uyulmuştur.

Toplam örneklemin \%52'si kadın \%48'i erkektir. Çoğunluğu orta yaştadır (30-39 yaş, \%47) ve 145'i (\%46) evlidir. İstanbul örnekleminde çift gelirli ailelerin sayısı daha fazla (\%55) olmakla birlikte, toplam örneklemde eşi çalışmayanların oranı (\%35) daha fazladır. Toplam örneklemde çocuğu olmayanların oranı \%59'dur. İlköğretim mezunu katılımcı sayısı \%7 iken, diğer eğitim düzeyi oranlarının birbirine oldukça yakın olduğu görülmektedir. Turizm eğitimi alanların oranı İstanbul örnekleminde \%60, Kuşadası'nda \%61'dir.

Örneklemin \%65'i en alt statüdeki personeldir. Örneklemin statü dağılımı yüksekten düşüğe doğru personel-şef-yönetici şeklindedir. Çalışılan departmanlara göre, İstanbul örnekleminde ofiste çalışanlar ${ }^{2}$ ve müşteri ile doğrudan iletişimde bulunanların ${ }^{3}$ oranı birbiriyle aynıdır (\%39). Kuşadası örnekleminin çoğunluğu (\%53) müşteri ile doğrudan iletişim gerektiren departmanlarda çalışmaktadır. Her iki örneklemde 5 yıl ve daha az deneyimi olan katılımcıların sayıları diğerlerine göre biraz daha fazladır (\%30). 21 yıl ve daha çok çalışma deneyimi olanların oranı \%46'ya \%32'lik farkla İstanbul'da daha fazladır. İki örneklemde de çalışma saatlerinin düzeni açısından vardiyalı çalışanlarla vardiyasız çalışanların oranları birbirine çok yakındır. Tüm örneklemde çalışma saatlerini antreli ve sözleşmeli olarak belirtenlerin oranı \%14'tür. Sosyo-ekonomik yönden, İstanbul katılımcılarının \%15'i ekonomik durumlarını alt, \%20'si orta-

\footnotetext{
${ }^{1} \mathrm{Bu}$ çalışma, "İ̧̧-aile çatı̧̧masının iş ve yaşam doyumuna etkilerinin iş stresi ve algılanan sosyal destek açısından otel personeli üzerinde incelenmesi" başlıklı doktora tezi olarak yürütülmüştür. Örneklem hakkında daha ayrıntılı bilgi için ilgili doktora tezine (bkz. Kaynakça bölümü) başvurulabilir.

2 Ofis seçeneği, Muhasebe, İnsan Kaynakları, Pazarlama, Satın alma, Genel İdare ve Banket-satış departmanların kapsamaktadır.

3 Müşteri ile doğrudan iletişim seçeneği, Önbüro, Restoran-servis, Misafir İşleri ve Sağlık Hizmetleri departmanlarını kapsamaktadır.
} 
üst seviye olarak tanımlamışlardır. Kuşadası katılımcılarının \%21'i ekonomik durumlarını alt, $\% 5$ 'i orta-üst seviye olarak belirtmişlerdir.

\section{ÖLÇÜMLER}

Çalışmada ele alınan değiş̧kenlerin ölçümü için, geçerlik ve güvenirliği önceki çalışmalarda test edilmiş olan standart ölçekler ve sosyo-demografik soru formu kullanılmıştır.

\section{İş-Aile Yaşam Çatışması Ölçeği}

Çalışanların iş-aile yaşam çatışması düzeylerini ölçmek üzere Netenmeyer ve arkadaşları (1996) tarafından geliştirilen, İAÇ (5 madde) ve AİÇ ( 5 madde) olmak üzere iki alt boyuttan oluşmaktadır. Ölçek maddeleri "İş sorumluluklarım aile yaşantımı olumsuz olarak etkiliyor", "Aileme karşı sorumluluklarım işimle ilgili yapmak istediğim şeyleri engelliyor" gibi yoruma açık olmayan, kafa karıştırmayan tek bir amaca yönelik maddelerdir. İfadelere cevaplar, 5'li Likert (1=kesinlikle katılmıyorum; 5=kesinlikle katılıyorum) tipi tepkilerle alınmaktadır.

\section{İş Doyumu Ölçeği}

Smith, Kendall ve Hulin tarafından (1969) yılında geliştirilen, işin yapısı, ücret, yükselme olanakları (kariyer), ast-üst ilişkisi (yönetim) ve çalışma arkadaşları boyutlarına ilişkin 25 madde bulunan ölçekte cevaplar 5'li Likert ölçeği ile alınmıştır.

İş Stresi Ölçeği "Sorumluluklarınızı yerine getirmek için yeterli yetkinizin olmadığını hisseder misiniz?" ya da "İşinizin aile hayatınıza engel olduğunu hisseder misiniz?" gibi 15 sorudan oluşan ölçekte, cevaplar 5'li zaman sıklığını (1=Hiçbir zaman; 2=Nadiren; 3=Bazen; 4=Sık sık; $5=$ Hemen hemen her zaman) ölçmeye yöneliktir. Ölçeğin değerlendirilmesinde toplam puan $15^{\prime} \mathrm{e}$ bölünerek bireyin ölçek puanı elde edilmekte ve yüksek puan yüksek stres seviyesini göstermektedir.

Yaşam Doyumu Ölçeği: Diener, Emmons, Larsen ve Griffin'nin (1985) geliştirdiği, "Yaşam koşullarım mükemmeldir", "Hayatımda sahip olmak istediğim her şeye sahibim” gibi 5 ifadeden oluşan ölçekten alınabilecek en düşük toplam puan 5, en yüksek toplam puan ise 25'iken; yüksek puan yüksek yaşam doyumunu göstermektedir.

Çok Boyutlu Algılanan Sosyal Destek Ölçeği: Zimet, Dahlen, Zimet ve Farley (1988) tarafından geliştirilen ölçeğin aile, arkadaş ve özel biri olmak üzere üç alt boyutu bulunmaktadır. 12 maddelik ölçekte en düşük toplam puan 12, en yüksek toplam puan ise 60'iken; yüksek puan algılanan yüksek destek seviyesini göstermektedir.

\section{Sosyo-demografik Soru Formu}

Cinsiyet, yaş, eğitim, medeni durum, çocuk sayısı, vb. özelliklerin yanı sıra iş özellikleri (statü, bölüm, görev, çalışma saatleri vb.) ve sosyo-ekonomik özellikleri (kişisel gelir, hane geliri, algilanan ekonomik durum) belirlemeye yönelik sorulara yer verilmiştir.

Kullanılan ölçeklerin araştırmada orijinal formları ile aynı faktör yapısında olup olmadığını doğrulamak ve iç tutarlılı̆̆ının değerlendirmek üzere, doğrulayıcı faktör analizi yapılmıs, ölçeklerin iç tutarlılık katsayıları hesaplanmıştır. Sonuçlar (iş doyumu ölçeği dışında), elde edilen verilerin, ölçeklerin orijinal ölçek faktör yapısına uygun olduğunu gösterdiği için ölçek maddelerinde büyük bir değişiklik yapılmaksızın ölçek puanları hesaplanmıştır. 
Tablo 1. Ölçeklere İlişkin Doğrulayıcı Faktör Analizi Sonuçları

\begin{tabular}{|l|c|c|c|c|c|c|}
\hline Ölçekler & $\mathrm{x}^{2} / \mathrm{df}$ & RMSEA & NNFI & CFI & AGFI & Cronbach $\alpha$ \\
\hline İAYÇÖ & 2,87 & 0,07 & $0,93(0,93)$ & 0,96 & $0,95(0,90)$ & 0.77 \\
\hline İAÇ & 2,70 & 0,07 & $0,95(0,92)$ & 0,97 & $0,99(0,95)$ & \\
\hline A $\dot{I} C ̧$ & 1,95 & 0,06 & $0,99(0,98)$ & 0,99 & $0,99(0,96)$ & \\
\hline İDÖ* $^{*}$ & 2,40 & 0,06 & $0,90(0,93)$ & 0,94 & $0,88(0,84)$ & 0.87 \\
\hline İÖO & 2,27 & 0,06 & $0,93(0,94)$ & 0,95 & $0,93(0,89)$ & 0.82 \\
\hline YDÖ & 1,16 & 0,02 & $0,99(0,99)$ & 1,00 & $0,99(0,98)$ & 0.72 \\
\hline ASDÖ & 3,08 & 0,08 & $0,99(0,97)$ & 0,99 & $0,98(0,92)$ & 0,72 \\
\hline
\end{tabular}

“İ̧s doyumu ölçeğinde 16. maddenin ( $\mathrm{r}=0.10)$ madde-toplam korelasyonu 0.20'nin (Büyüköztürk, 2002) altında olduğundan ölçekten çıkarılmıştır.

\section{İstatistiksel Analiz}

Araştırma verilerinin istatistiksel analizinde SPSS 22.0 paket programı kullanılmıştır. Çalışma kapsamındaki ölçeklerin ve alt boyutlarının aralarındaki ilişkiler için Pearson korelasyon analizi yapılmış, bu değişkenlerin birbirini yordama gücü için basit doğrusal regresyon analizleri uygulanmıştır. İAYÇ ile doyum değişkenleri ilişkide bazı değişkenlerin aracilığı SOBEL testi (Sobel, 1982) ile incelenmiştir. Sobel testi, bağımsız değişkenin (aracı değişken vasıtasıyla) bağımlı değişken üzerindeki dolaylı etkisinin anlamlı olup olmadığını saptamak amacıyla geliştirilmiş bir test olup, etki büyüklüğü toplam etki puanından doğrudan etki puanının çıkartılması ölçülebilmektedir (Sobel, 1982). Baron ve Kenny (1986), aracı değişkenin etkisini analiz edebilmek için üç kriterin gerçekleşmesi gerektiğini ifade eder. İlk kriter, bağımsız değişkenin aracı değişken üzerinde anlamlı olarak etkisi olmalı (a yolu), ikinci olarak aracı değişkenin, bağımlı değişken üzerinde anlamlı olarak etkisi olmalı (b yolu), son olarak da bağımsız değişken, bağımlı değişken üzerinde anlamlı etkiye sahip olmalıdır (c yolu). Çalışma kapsamında aracı değişkenin etkisini değerlendirmek için Hayes'in (2016) SPSS programı eklentisi olan PROCESS yazılımı kullanılarak 4. Model ile analizler gerçekleştirilmiş, bootstrap güven aralığının alt ve üst sınırın sıfırın altında veya üstünde olmasına göre aracılık etkisi yorumlanmiştır (Field, 2013).

\section{BULGULAR ve TARTIŞMA \\ Ölçek Puanlarının Dağılımı}

Araştırmada ele alınan değişkenlere ilişkin puan dağılımları İstanbul, Kuşadası ve toplam örneklem için ayrı ayrı olmak üzere Tablo 2'de gösterilmiştir. İstanbul ve Kuşadası'daki katılımcıların puan ortalamaları karşılaştırıldığında t-test sonuçları İAYÇ yaşama düzeylerinin farklı olduğunu göstermektedir (İAÇ için, $\mathrm{t}_{221,301}=2,70\left(\mathrm{p}<.01\right.$ ), AİÇ için ise $\mathrm{t}_{242,281}=2,24(\mathrm{p}<.05$ ). İAÇ puanlarının Kuşadası'nda (ort Kuşadası =3,06; ort istanbul=2,82), AİÇ puanlarının ise İstanbul'da daha yüksek (ort Kuşadası = 2,21; ort istanbul=2,43) olduğu görülmektedir. Öte yandan her iki örneklemin puan ortalamaları karşılaştırıldığında, İAÇ'nin AİÇ'ye nazaran daha çok yaşandığı görülmektedir (Tablo 2).

İş doyumunun alt boyutlarından genel iş doyumu $(\mathrm{p}=.015)$ ve ücretten doyum $(\mathrm{p}=.008)$ açısından da iki örneklem arasında farklılık bulunmuştur. [Sırasıyla, $\mathrm{t}_{256,494}=2,44(\mathrm{p}<.05), \mathrm{t}_{2,681}$ $=2,68(\mathrm{p}<.01)]$. Genel iş doyumu puan ortalaması Kuşadası, ücretten doyum puanları İstanbul örnekleminde daha yüksektir. Yaşam doyumu puanları da istatistiksel açıdan farklıdır $\left(\mathrm{t}_{4,001}=4,00\right.$ ( $\mathrm{p}<.001$ ). Buna göre İstanbul örnekleminde yaşam doyumu puan ortalamaları daha yüksektir. İki örneklem arasında, iş stresi ve algılanan sosyal destek puan ortalamaları bakımından istatistiksel olarak anlamlı bir fark bulunmamıştır. 
Tablo 2. Çalışmada Kullanılan Ölçeklerin Puan Dağılımları

\begin{tabular}{|c|c|c|c|c|c|c|c|c|}
\hline \multirow{2}{*}{ Ölçekler } & \multicolumn{2}{|c|}{ İstanbul } & \multicolumn{2}{|c|}{ Kuşadası } & \multicolumn{2}{|c|}{ Toplam } & \multirow{2}{*}{$\mathbf{t} / \mathbf{F}$} & \multirow{2}{*}{ df } \\
\hline & Ort. & S.S. & Ort. & S.S. & Ort. & S.S. & & \\
\hline $\begin{array}{r}\text { İş-Aile Yaşam Çatışması Ölçeği } \\
\text { İş-aile Çatışması }\end{array}$ & 2,82 & ,77 & 3,06 &, 77 & 2,90 & ,78 & $2,70^{* *}$ & 221,30 \\
\hline Aile-iş Çatışması & 2,43 & 87 & 2,21 & ,78 & 2,35 & 84 & $2,24^{*}$ & 242,28 \\
\hline $\begin{array}{l}\text { İş Doyumu Ölçeği } \\
\text { Genel İş Doyumu }\end{array}$ & 3,54 & ,63 & 3,71 &, 53 & 3,60 &, 60 & $2,44^{*}$ & 256,49 \\
\hline Ücretten Doyum & 2,89 & 81 & 2,63 & 85 & 2,80 & 83 & $2,68^{* *+}$ & 214,73 \\
\hline İş Stresi Ölçeği & 2,40 & ,63 & 2,36 &, 57 & 2,39 & ,61 &, 55 & 245,18 \\
\hline Yaşam Doyumu Ölçeği & 2,91 & ,77 & 2,54 & 81 & 2,78 & 81 & $4,00^{* * *+}$ & 214 \\
\hline Algılanan Sosyal Destek Ölçeği & 3,87 & 1,10 & 3,71 & 1,30 & 3,81 & 1,17 & 214 & 192,75 \\
\hline
\end{tabular}

${ }^{*} 0,01$ seviyesinde anlamll, ${ }^{* *} 0,05$ seviyesinde anlaml

\section{İlişkisel Analizler \\ İş-Aile Yaşam Çatışması, İş ve Yaşam Doyumu, İş Stresi ve Algılanan Sosyal Destek Değişkenlerinin Birbirleriyle İlişkileri}

Ölçek puanları arasındaki ilişkilerin düzeyini ve yönünü belirlemek amacı ile öncelikle Pearson korelasyon katsayıları hesaplanmıştır. Tablo 3'den görüldüğü gibi, AİÇ ile İAÇ puanları arasında pozitif ve anlamlı bir korelasyon vardır. AİÇ'nin iş stresi ile pozitif yönde korelasyonlu olduğu bulunmuştur. AİÇ ile genel iş doyumu, yaşam doyumu ve algılanan sosyal destek düzeyleri arasında negatif ve anlamlı korelasyonlar hesaplanmıştır. İAÇ'nin pozitif ve anlamlı ilişkili olduğu tek değişken iş stresidir. Genel iş doyumu, ücretten doyum ve yaşam doyumu ile negatif ilişkilidir. Katılımcıların İAÇ düzeyleri artma eğilimi gösterdikçe, işin genelinden ve ücretten doyum düzeyleri azaldığı gibi, yaşam doyumlarında da düşme eğilimi görülmektedir. ASD ile İAÇ ilişkisi anlamlı bulunmamıştır. Genel iş doyumu, iş stresi dışında tüm değişkenler ile pozitif ilişkilidir. Tablo 3'de ücretten doyum puanlarının diğer ölçek puanları ile korelasyonları incelendiğinde, yaşam doyumu ASD ile pozitif ilişkili olduğu görülürken, iş stresi ile negatif yönlü bir iliş̧ki olduğu görülmektedir. İş stresi yaşam doyumu ilişkisi negatif yönlü iken, yaşam doyumu ASD ilişkisi pozitiftir ( $\mathrm{r}=.171)$. Ölçek puanları arasındaki korelasyonlar İstanbul ve Kuşadası için ayrı ayrı da hesaplanmıştır (Tablo 3). İstanbul örnekleminde, AİÇ ve İAÇ puanları pozitif ilişkilidir. AİÇ ücretten doyum ve iş stresi dışındaki değişkenlerle negatif ilişkili; İAÇ genel iş doyumu, ücretten doyum ve yaşam doyumu ile negatif; iş stresi ile pozitif ilişkilidir. Genel iş doyumu puanlarının diğer ölçek puanları ile ilişkisi için hesaplanan korelasyonlar istatistiksel düzeyde anlamlı ve iş stresi dışında pozitiftir. Genel iş doyumu puanlarının, ücretten doyum, yaşam doyumu ve ASD ile ilişkileri pozitif yöndedir. Tablo 3'den görüldüğü gibi, iş stresi puanları, yaşam doyumu ile negatif yönde, ASD ile pozitif yönde ilişkili bulunmuştur. Analiz sonuçları Kuşadası örneklemi için incelendiğinde, AİÇ'nin İAÇ ve iş stresi puanları ile pozitif yönde ilişkili olduğu görülmektedir. AİÇ'nin negatif yönde ilişkili olduğu değişkenler doyum değişkenleridir. İAÇ iş stresi ile pozitif ilişkili iken ASD hariç diğer değişkenler ile negatif yönde ilişkilidir. 
İş Stresi, Algılanan Sosyal Destek, İş ve Yaşam Doyumunun, İş-aile Yaşam Çatışmasını Yordayıcılığı

Çalışmada, iş stresi, ASD, iş ve yaşam doyumunun bireylerin İAYÇ düzeylerine etkisini belirlemek için bir dizi basit doğrusal regresyon analizi uygulanmıştır. Test edilen ilk model İAÇ'nin yordanan değişken olduğu, AİÇ, toplam iş doyumu, iş stresi, yaşam doyumu ve ASD'nin yordayıcı değişkenler olduğu bir modeldir (Tablo 4). Sonuçlar AİÇ, iş ve yaşam doyumunun İAÇ'nin anlamlı yordayıcıları olduğunu göstermektedir $\left(\mathrm{F}(5,310)=27,606, \mathrm{p}<.000 ; \mathrm{R}^{2}=.31\right)$. İkinci olarak, AIÇ yordanan, İAÇ, toplam iş doyumu, iş stresi, yaşam doyumu ve ASD'nin yordayıcı olduğu bir model test edilmiştir (Tablo 4). Modele ait analiz sonuçları, İAÇ ile iş stresinin, AİÇ'nin anlamlı birer yordayıcısı olduğunu göstermiştir $\left(F(5,310)=20,802, p<.000 ; R^{2}=.25\right)$. Üçüncü modelde, yaşam doyumu yordanan; İAÇ, AİÇ, toplam iş doyumu, iş stresi ve ASD yordayıc1 olarak alınmıştır (Tablo 5). AİÇ ile yaşam doyumu arasında \%95 güven aralığında negatif ve anlamlı bir ilişki $(\mathrm{r}=-.20)$ bulunmuş olsa da regresyon analizi sonucuna göre AİÇ yaşam doyumu yordayıcılığı anlamlı bulunmamıştır. AİÇ dışındaki diğer değişkenler, yaşam doyumunun anlamlı birer yordayıcısıdır $\left(\mathrm{F}(5,310)=19,550, \mathrm{p}<.000 ; \mathrm{R}^{2}=.24\right)$. (Tablo 5). Toplam iş doyumunun (genel iş ve ücretten doyum) yordanan değişken, yordayıcılarının ise AİÇ, İAÇ, iş stresi, yaşam

Tablo.3. Ölçekler ve Alt Boyutları Arasındaki Korelasyonlar

\begin{tabular}{|c|c|c|c|c|c|c|c|}
\hline ÖLÇEKLER & AİÇÖ & İAÇÖ & G.Doyum & Ü.Doyum & İSÖ & YDÖ & ASDÖ \\
\hline AİÇÖ & 1 & $498^{* *}$ &,$- 365^{* *}$ &,$- 291^{* *}$ &, $462^{* *}$ &,$- 333^{* *}$ &,- 086 \\
\hline İAÇÖ & & 1 &,$- 369^{* *}$ &,$- 312^{* *}$ & ,305* &,$- 305^{* *}$ &,- 087 \\
\hline G.Doyum & & & 1 &, $445^{* *}$ &,$- 522^{* *}$ &, $228^{*}$ & ,008 \\
\hline Ü.Doyum & & & & 1 &,$- 367^{* *}$ &, $555^{* *}$ & ,117 \\
\hline İSÖ & & & & & 1 &,$- 264^{* *}$ &,- 035 \\
\hline YDÖ & & & & & & 1 & ,036 \\
\hline ASDÖ & & & & & & & 1 \\
\hline İSTANBUL & AİÇÖ & İAÇÖ & G.Doyum & Ü.Doyum & İSÖ & YDÖ & ASD \\
\hline AİÇÖ & 1 &, $507^{* *}$ &,$- 188^{* *}$ &,- 001 &, 132 &,$- 186^{* *}$ &,$- 182^{* *}$ \\
\hline İAÇÖ & & 1 &,$- 361^{* *}$ &,$- 202^{* *}$ &, $177^{*}$ &,$- 274^{* *}$ & -100 \\
\hline G.Doyum & & & 1 &, $577^{* *}$ &,$- 504^{* *}$ & $467^{* *}$ & 190** \\
\hline Ü.Doyum & & & & 1 & $-197^{* *}$ & $416^{* *}$ & , 120 \\
\hline İSÖ & & & & & 1 &,$- 418^{* *}$ &,- 098 \\
\hline YDÖ & & & & & & 1 & ,244 \\
\hline ASDÖ & & & & & & & 1 \\
\hline KUŞADASI & AİÖ & İAÖ & G.Doyum & Ü.Doyum & İSÖ & YDÖ & ASDÖ \\
\hline AiÖ & 1 &, $476^{* *}$ &,$- 251^{* *}$ &,- 078 &, $233^{* *}$ &,$- 200^{* *}$ &,$- 136^{*}$ \\
\hline İAÖ & & 1 &,$- 335^{* *}$ &,$- 259^{* *}$ &, $211^{* *}$ &,$- 308^{* *}$ &,- 103 \\
\hline G.Doyum & & & 1 &, $502^{* *}$ &,$- 508^{* *}$ &, $347^{* *}$ &, $115^{*}$ \\
\hline Ü.Doyum & & & & 1 & $-245^{* *}$ &, $484^{* *}$ &, $126^{*}$ \\
\hline İSÖ & & & & & 1 &,$- 350^{* *}$ &,- 072 \\
\hline YDÖ & & & & & & 1 &, $171^{* *}$ \\
\hline ASDÖ & & & & & & & 1 \\
\hline
\end{tabular}

doyumu ve ASD olduğu son model de basit doğrusal regresyon analizi ile test edilmiş, İAÇ, iş stresi ve yaşam doyumu, toplam iş doyumunun anlamlı yordayıcıları olarak bulunmuştur ( $\mathrm{F}$ $\left.(5,310)=33,821, \mathrm{p}<.000 ; \mathrm{R}^{2}=.35\right)$. 
Tablo 4. Çatışma Değişkenleri İçin Basit Doğrusal Regresyon Analizi Sonuçları

\begin{tabular}{|c|c|c|c|c|c|c|c|c|c|c|c|}
\hline \multirow{2}{*}{$\begin{array}{l}\text { Yordanan } \\
\text { Değişken }\end{array}$} & \multirow{2}{*}{ Yordayıcı Değişken } & \multirow{2}{*}{$\mathbf{R}$} & \multirow{2}{*}{$\mathbf{R}^{2}$} & \multirow{2}{*}{$\mathbf{F}$} & \multirow{2}{*}{$\mathbf{p}$} & \multirow{2}{*}{ B } & \multirow{2}{*}{ Beta } & \multirow{2}{*}{$\mathbf{t}$} & \multirow{2}{*}{$\mathbf{p}$} & \multicolumn{2}{|c|}{ \%95 Güven Aralığı } \\
\hline & & & & & & & & & & Alt & Üst \\
\hline \multirow{6}{*}{ İş-Aile Çatışması } & MODEL & ,555 & ,308 & 27,606 & ,000 & & & & & & \\
\hline & AİLE-İŞ ÇATIŞMASI & & & & & ,373 & ,405 & 8,184 & ,000 & ,283 &, 462 \\
\hline & TOPLAM İŞ DOYUMU & & & & &,- 305 &,- 221 & $-3,851$ &, 000 &,- 462 &,- 149 \\
\hline & İŞ STRESİ & & & & &,- 057 &,- 045 &,- 809 & 419 &,- 197 &, 082 \\
\hline & YAŞAM DOYUMU & & & & &,- 146 &,- 152 & $-2,833$ & ,005 &,- 247 &,- 045 \\
\hline & A. SOSYAL DESTEK & & & & & , 002 & ,003 & , 072 & ,942 &,- 061 &, 065 \\
\hline \multirow{6}{*}{ Aile - İş Çatışması } & MODEL &, 501 & ,251 & 20,802 & ,000 & & & & & & \\
\hline & İŞ-AİLE ÇATIŞMASI & & & & & 477 & 438 & 8,184 & ,000 &, 362 &, 591 \\
\hline & TOPLAM İŞ DOYUMU & & & & & ,005 & ,003 & ,055 & ,956 &,- 176 & , 186 \\
\hline & İŞ STRESİ & & & & & 186 & 134 & 2,336 & 020 &, 029 & ,342 \\
\hline & YAŞAM DOYUMU & & & & &,- 006 &,- 005 &,- 094 & ,925 &,- 122 & ,110 \\
\hline & A. SOSYAL DESTEK & & & & &,- 058 &,- 081 & $-1,621$ & ,106 &,- 129 & ,012 \\
\hline
\end{tabular}

Tablo 5. Doyum Değişkenleri İçin Basit Doğrusal Regresyon Analizi Sonuçları

\begin{tabular}{|c|c|c|c|c|c|c|c|c|c|c|c|}
\hline \multirow{2}{*}{$\begin{array}{l}\text { Yordanan } \\
\text { Değişken }\end{array}$} & \multirow[t]{2}{*}{ Yordayıcı Değişken } & \multirow[t]{2}{*}{$\mathbf{R}$} & \multirow[t]{2}{*}{$\mathbf{R}^{2}$} & \multirow[t]{2}{*}{$\mathbf{F}$} & \multirow[t]{2}{*}{$\mathbf{p}$} & \multirow[t]{2}{*}{ B } & \multirow[t]{2}{*}{ Beta } & \multirow[t]{2}{*}{$t$} & \multirow[t]{2}{*}{ p } & \multicolumn{2}{|c|}{$\begin{array}{l}\text { \%95 } \\
\text { Güven Aralığı }\end{array}$} \\
\hline & & & & & & & & & & Alt & Üst \\
\hline \multirow{6}{*}{ Yaşam Doyumu } & MODEL & 490 & ,240 & 19,550 &, 000 & & & & & & \\
\hline & AİÇ & & & & &,- 005 &,- 005 &,- 094 & ,925 &,- 113 & ,103 \\
\hline & İAÇ & & & & &,- 173 &,- 166 & $-2,833$ & ,005 &,- 293 &,- 053 \\
\hline & (TOPLAM) İDÖ & & & & & ,365 & ,254 & 4,247 & , 000 & ,196 &, 534 \\
\hline & İSÖ & & & & &,- 238 &,- 180 & $-3,124$ & ,002 &,- 387 &,- 088 \\
\hline & ASDÖ & & & & &, 074 & ,107 & 2,132 & , 034 & ,006 & , 142 \\
\hline \multirow{6}{*}{$\begin{array}{l}\text { Toplam } \\
\text { İş Doyumu* }\end{array}$} & MODEL & ,594 & ,353 & 33,821 & ,000 & & & & & & \\
\hline & AİÇ & & & & & ,002 & ,003 & ,055 & ,956 &,- 067 & ,071 \\
\hline & İAÇ & & & & &,- 149 &,- 207 & $-, 3,851$ & ,000 &,- 226 &,- 073 \\
\hline & İSÖ & & & & &,- 342 &,- 372 & $-7,510$ & ,000 &,- 432 &,- 253 \\
\hline & YDÖ & & & & & 151 & ,216 & 4,247 & ,000 & ,081 & 220 \\
\hline & ASDÖ & & & & & ,021 & ,045 & ,959 & ,338 &,- 023 &, 065 \\
\hline
\end{tabular}

${ }^{*}$ Toplam iş doyumu, genel iş doyumu ve ücretten doyumu kapsamaktadır 


\section{İş Stresi, Algılanan Sosyal Destek, İAYÇ ve Yaşam Doyumuna Etkisine İlişkin Model Testleri}

Bazı değişkenlerin İAYÇ ile doyum değişkenleri arasındaki ilişkide aracılık rolünü incelemek üzere bir dizi Sobel Testi yapılmış ve dolaylı etkinin anlamlılı̆̆ için bootstrap güven aralığı sonuçlarına göre yorumlanmıştır. Buna göre Aracılık etkileri istatistiksel olarak sadece aile-iş çatışması ve iş-aile çatışması ile yaşam doyumu ilişkisinde anlamlı bulunmuştur. (Algılanan sosyal desteğin aracı değişken olarak test edildiği modellere ilişkin sonuçlara göre boot değerleri arasında 0 değeri bulunduğundan sonuçlar değerlendirilmemiş̧ir.) Analizlerin sonuçlarına göre, AİÇ'nin iş doyumunu üzerindeki toplam etkisi anlamlıdır $(\beta=-0,2569)$. İş stresinin aracılığı incelendiğinde bu etki azalmakla birlikte hala anlamlı düzeydedir $(\beta=-0,1899)$. İşs stresinin aracılık etkisinden kaynaklanan dolaylı etkinin de anlamlı olduğu görülmektedir $(\beta=-0,0671)$. Dolayısıyla iş stresi bu ilişkide kısmi aracı role sahiptir.

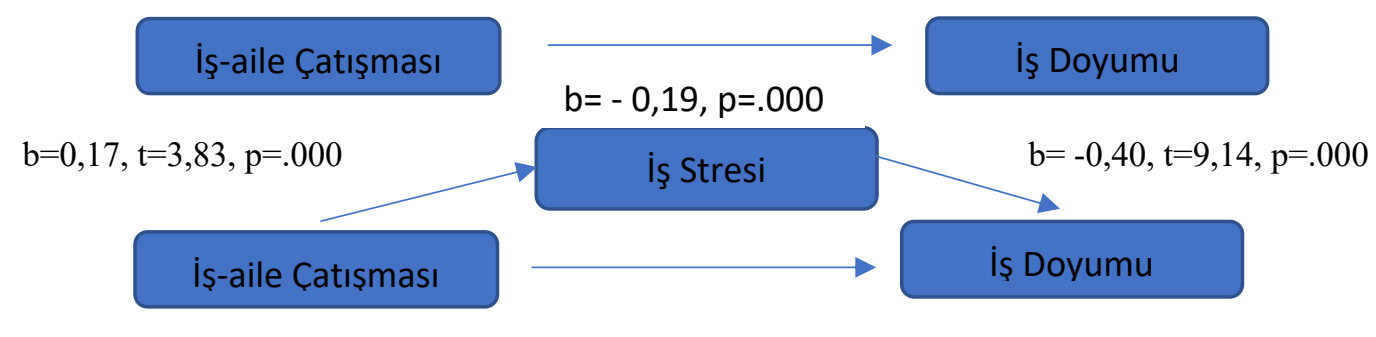

Dolaylı etki, $b=-0,0795 \%$ CI [- 0,11, - 0,02]

Şekil 1. İş-aile Çatışması ve İş Doyumu İlişkisinde İş Stresinin Aracılık Etkisi

İkinci model test edildiğinde, AİÇ’nin iş doyumu üzerindeki toplam etkisinin anlamlı olduğu bulunmuştur $(\beta=-0,1541)$. İş stresinin aracıllı̆̆ eklendiğinde etki azalmakla birlikte hala anlamlı düzeydedir $(\beta=-0,0819)$. İş stresinin aracılık etkisinden kaynaklanan dolaylı etkisinin de anlamlı olduğu görülmektedir $(\beta=-0,0722)$. Dolayısıyla iş stresi bu ilişkide kısmi aracı role sahiptir.

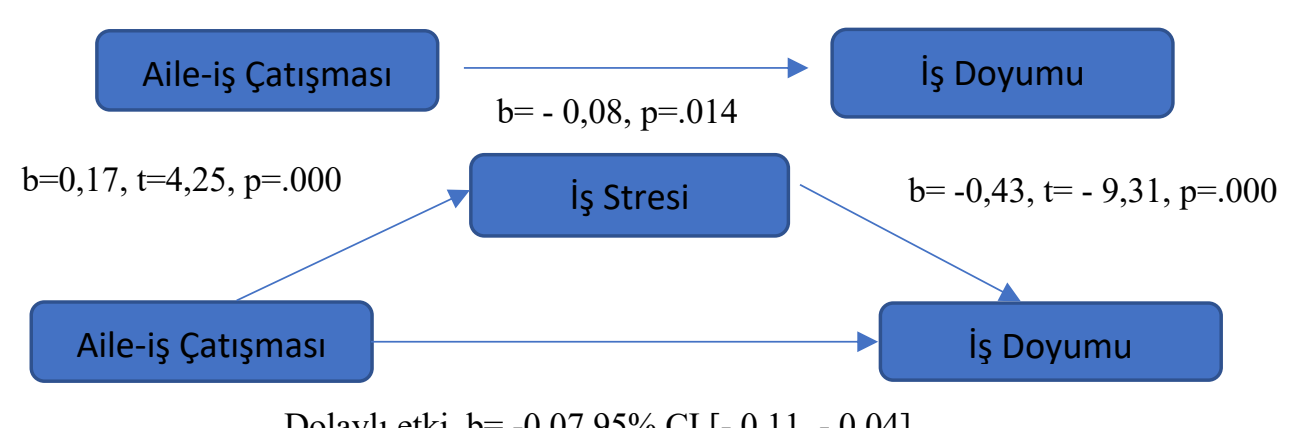

Dolaylı etki, $b=-0,0795 \%$ CI [- 0,11, - 0,04]

\section{Şekil 2. Aile-iş Çatışması ve İş Doyumu İlişkisinde İş Stresinin Aracılık Etkisi}

Test edilen üçüncü modelde, İAÇ'nin yaşam doyumu üzerindeki toplam etkisi anlamlıdır $(\beta=-0,3205)$. İş doyumunun aracılığı varken bu etki azalmakla birlikte hala anlamlı düzeydedir $(\beta=-0,1905)$. İş doyumunun aracılık etkisinden kaynaklanan dolaylı etkisinin de anlamlı olduğu görülmektedir $(\beta=-$ 0,1301). İş doyumu kısmi aracı rolüne sahiptir. 


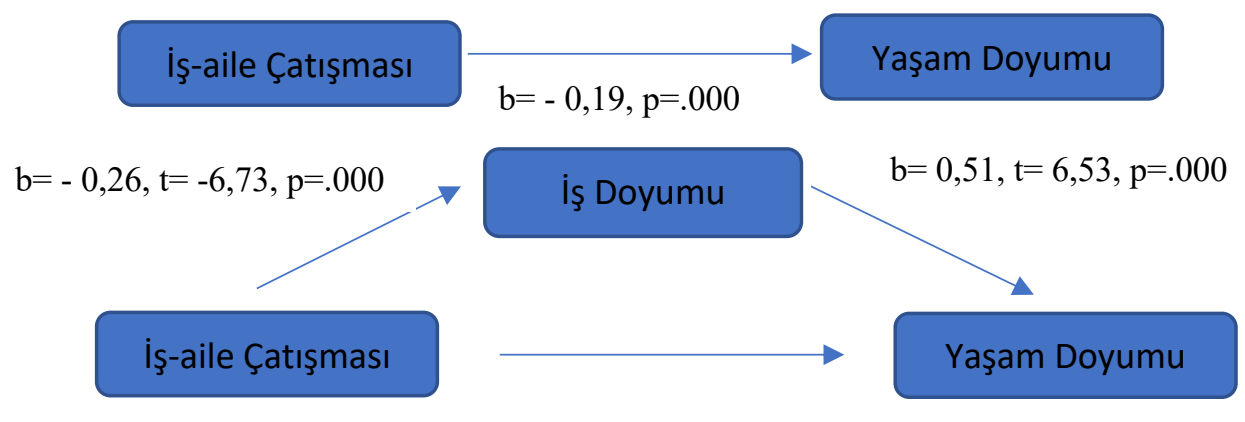

Dolaylı etki, $b=-0,13$ 95\% CI [- 0,19, -0,07]

Şekil 3. İş-aile Çatışması ve Yaşam Doyumu İlişkisinde İş Doyumunun Aracılık Etkisi

Bir diğer modelde, AİÇ'nin yaşam doyumunu üzerindeki toplam etkisi anlamlıdır $(\beta=-0,1912)$. İş doyumunun aracıllğg eklenince bu etki azalmakla birlikte hala anlamlı düzeydedir $(\beta=-0,1044)$. İş doyumunun aracılık etkisinden kaynaklanan dolaylı etkisinin de anlamlı olduğu görülmektedir $(\beta=-$ 0,0868) olduğu görülmektedir. İş doyumu bu ilişkide kısmi aracı role sahiptir.

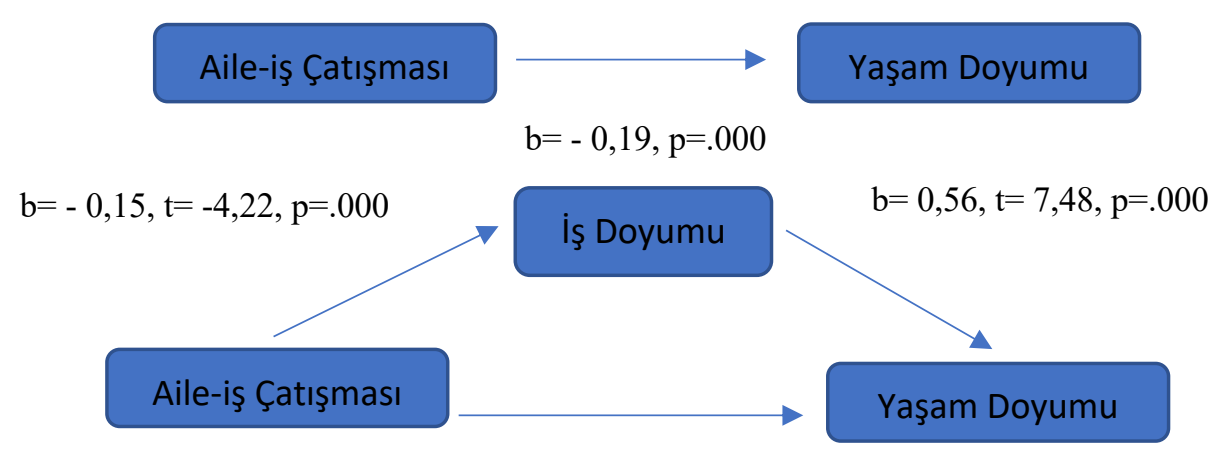

Dolaylı etki, $b=-0,0995 \%$ CI $[-0,15,-0,04]$

Şekil 4. Aile-iş Çatışması ve Yaşam Doyumu İlişkisinde İş Doyumunun Aracılık Etkisi

Test edilen son modelde, AIÇ'nin yaşam doyumunu üzerindeki toplam etkisi anlamlıdır $(\beta=-0,1912)$. ASD'nin bu ilişkide aracı olması durumunda bu etki azalmakla birlikte hala anlamlı düzeydedir $(\beta=-$ $0,1721)$. ASD'nin aracılık etkisinden kaynaklanan dolaylı etkisinin de anlamlı olduğu görülmektedir ( $\beta$ $=-0,0191)$. ASD bu ilişkide kısmi aracı role sahiptir.

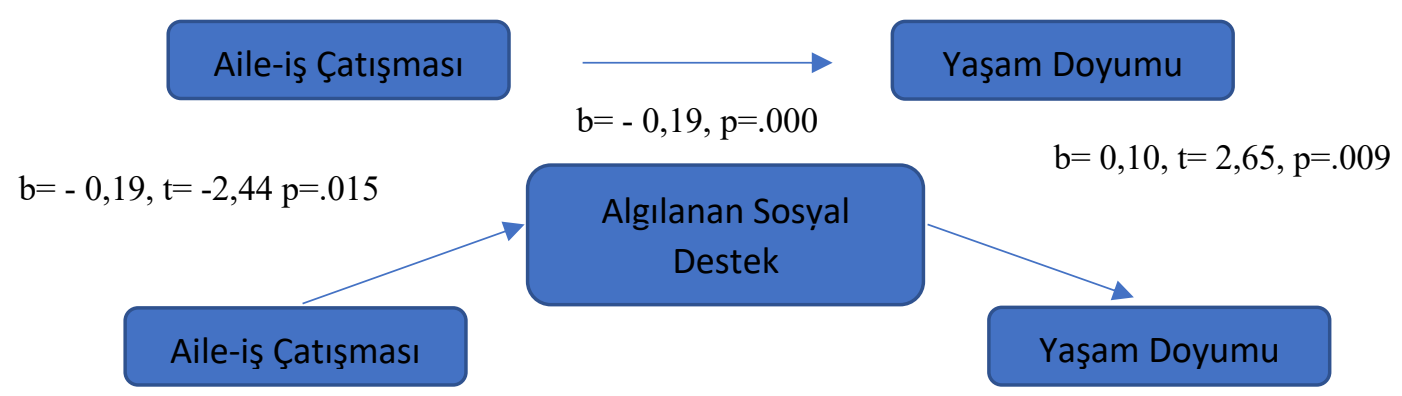

Dolaylı etki, $b=-0,0295 \%$ CI $[-0,04,-0,01]$

Şekil 5. Aile-iş Çatışması ve Yaşam Doyumu İlişkisinde Algılanan Sosyal Desteğin Aracılık Etkisi 


\section{TARTIŞMA, SONUÇ ve ÖNERILLER}

Bu çalışmayla, İstanbul ve Kuşadası'nda faaliyet gösteren beş yıldızlı otel işletmelerinde çalışanların çatışma (iş-aile/aile-iş) ve doyum (iş/yaşam) ilişkilerinin, algılanan sosyal destek ve iş stresi faktörleri ile birlikte incelenmesi amaçlanmıştır.

Çatışma ve doyum literatürü, bu iki kavramın ilişkisi hakkında net bir durum ortaya koyamamaktadır. Bu sebeple çalışmada öncelikle, çatışmanın (iş-aile/aile-iş) doyumsuzluğun (iş ve yaşam) bir sonucu olabildiğine ilişkin literatüre dayanılarak (Özdevecioğlu ve Doruk, 2009; Yurtseven, 2008; Efeoğlu, 2006; Öcal, 2008) ve aralarında bir korelasyon olduğunun da bulunmasıyla birlikte, doyum değişkenleri (iş ve yaşam), iş stresi ve algılanan sosyal desteğin yordayıcı olarak ele alındığı bir dizi regresyon analizi yapılmıştır. Buna göre İAÇ nin yordanan değişken olduğu, AİÇ, toplam iş doyumu, iş stresi, yaşam doyumu ve ASD nin yordayıcı değişkenler olarak test edilen ilk modelin sonuçları, İAÇ yi yordayan değişkenlerin, AİÇ, iş doyumu ve yaşam doyumu olduğunu göstermektedir. Bulgu, Ai̇Ç ile İAÇ arasında ilişki olduğunu (Doruk, 2008; Yurtseven, 2008) ve iş-yaşam doyumunun bireyi genel olarak etkilediğini ifade eden literatür ile tutarlıdır (Özdevecioğlu ve Doruk, 2009).

AİÇ nin yordanan değişken olduğu, İAÇ, toplam iş doyumu, iş stresi, yaşam doyumu ve ASD nin ise yordayıcı değişkenler olduğu ikinci modele ilişkin analiz sonuçları ise, iş-aile çatışması ile iş stresinin, aile-iş çatışmasının anlamlı birer yordayıcısı olduğunu göstermiştir. Çatışma değişkenlerinin yordayıcı değişken olarak test edildiği her iki modelde de algılanan sosyal desteğin, çatışmaları (iş-aile/aile-iş) yordama etkisinin olmadığı görülmüştür. Literatürde, çatışmanın yordanan doyumun ise yordayıcı değişken olarak test edildiği herhangi bir çalışmaya rastlanmadığından sonuçlarının karşılaştırılma imkânı bulunamamıştır.

Bir sonraki aşamada doyum değişkenlerinin (iş ve yaşam) yordanan değişken olarak ele alındığ1 regresyon analizleri yapılmıştır. İlk model olarak yaşam doyumunun yordanan değişken olarak belirlendiği modelde, yaşam doyumunun yordayıcılarının iş-aile çatışması, toplam iş doyumu, iş stresi ve algılanan sosyal destek olduğu belirlenmiştir. İkinci modelde yordanan değişken olarak iş doyumu test edilirken, iş-aile çatışması, iş stresi ve yaşam doyumu iş doyumunun anlamlı yordayıcıları olarak bulunmuştur. Modelde aile-iş çatışmasının iş doyumunu yordama etkisinin bulunmaması, ücretten doyum ile arasında anlamlı bir korelasyon bulunmaması ile açıklanabilir. Ancak aksini belirten çalışmalar da mevcuttur. Dursun ve İştar'ın (2014) aile-iş çatışmasının iş ve yaşam doyumu üzerine etkisine yönelik regresyon analizi sonuçları aile-iş çatışmasının iş doyumu üzerinde negatif yönlü anlamlı bir etkisi olduğu sonucuna varılmıştır. Literatürde iş doyumunun yordanan değişken olarak modellendiği çalışmalarda yordayıcıları iş-aile çatışması, aile-iş çatışması ve yaşam doyumu olarak belirlenmiş fakat çalışmalar değişkenlerin hepsinin bir arada test edildiği modeller üzerinden yapılmamış, yordayıcıların iş doyumunu tek tek yordama gücüne bakılmıştır.

Diğer taraftan çalışma kapsamında yapılan korelasyon analizine yönelik bulgular, AİÇ ile İAÇ ölçek puanları arasındaki korelasyonların gerek tüm örneklemde gerek ayrı ayrı İstanbul ve Kuşadası örneklemlerinde pozitif ve anlamlı ilişkide olduğunu göstermiştir. Dolayısıyla çalışanların İAÇ düzeyleri arttıkça, AİÇ düzeyleri de artmakta ya da tam tersi çatışma boyutlarından biri azaldıkça diğeri de azalmaktadır. İlgili literatürde sonucu destekleyen çalışmalar mevcuttur (Üzümcü ve Akpulat, 2017; Benli, Yenihan ve Öner, 2016; Fırat ve Cula, 2016). Puan ortalamaları, her iki çatışma türünün yaşanma yoğunluğunun orta düzeyde olmakla birlikte, İAÇ'nın AİÇ’na göre daha çok yaşandığını göstermiştir. Turizm sektöründe yapılan diğer çalışmalarla (Yurtseven, 2008; Diker, 2010; Çakır, 2011) da bu çalışma sonuçlarının tutarlı olduğu görülmüştür. Ev işlerinin daha esnek olmasıyla birlikte bireyin işe ve gelire olan ihtiyacının zaruriyeti nedeniyle her zaman işin aile alanına göre öncelikli olması günümüz koşullarında anlaşılır bir durumdur. 
Çatışma puanları örneklem açısından değerlendirildiğinde, Kuşadası'nda İAÇ'nın, İstanbul'da ise AİÇ'nın daha fazla yaşandığı görülmüştür. Kuşadası otellerinin İstanbul'dakilere nazaran kurumsallıktan biraz daha uzak yapıda olmalarının beraberinde getirdiği uzun/belirsiz çalışma saatleri, iş belirsizlikleri, stresli ve yoğun çalışma ortamı gibi sıkıntıların çalışanların aile yaşamlarına etki ettiği bu nedenle İAÇ yaşanma oranlarının daha yüksek olduğu düşünülmektedir. AİÇ'nın İstanbul'da daha fazla yaşanması ise aile yapısından kaynaklanabilir.

Çatışma ve doyum ters ilişkili olduğu için, bireylerin Aİç düzeyleri arttıkça genel iş doyumu, yaşam doyumu ve ASD düzeylerinde azalma eğilimi görülmüştür. Ya da tam tersi bireylerin doyum ve ASD düzeylerindeki artış eğilimi, yaşadıkları aile-iş çatışmasının azalması yönünde etki etmektedir. Diğer taraftan evde yaşananların işe, işte yaşananların ise eve yansımaması oldukça güçtür (Eren, 2000; Arslan, 2010). Nitekim bu çalışmada da İAYÇ ile iş stresi ilişkisinde pozitif yönlü ilişki görülmüştür. Karakaş ve Şahin (2017); Deveci (2016) gibi literatürde yer alan bazı araştırmalar da sonucu desteklemektedir. Lindorff (2001), çalışanların iş stresi düzeyini azaltan ya da arttıran unsurlardan birisinin yakın çevresinden gördüğü sosyal destek olduğunu ifade etmektedir. Puan ortalamaları değerlendirildiğinde, iş stresi, yaşam doyumu ve ASD açısından İstanbul ölçek puan ortalamaları Kuşadası örneklemine göre görece daha yüksek hesaplanmıştır.

Çalışma, turizm sektörü çalışanlarının İAYÇ, iş ve yaşam doyumu, iş stresi ve ASD düzeylerini sınırlı bir örneklemden hareketle ortaya koyarken, çalışanların iş ve yaşam doyum düzeylerinin ele alınan değişkenlerden nasıl etkilendiğini de göstermiştir. Çalışmada ele alınan bazı değişkenlerin aralarında korelasyon bulunmasına rağmen regresyon modelinde yordayıcı olarak istatistiksel olarak anlamlı bir etki yaratmaması çatışma (iş-aile/aile-iş) ve doyum (iş/yaşam) arasındaki ilişkide bir aracı değişken olabileceğini akla getirmiştir.

Değişkenler arasındaki korelasyona ve literatüre dayanılarak yapılan regresyon analizleri sonuçları, AİÇ, iş ve yaşam doyumu değişkenlerinin İAÇ varyansının \%32'sini açıkladığını göstermiştir. AİÇ varyansın \%25'ini ise İAÇ ve iş stresi açılamaktadır. Doyum değişkenleri incelendiğinde, AİÇ dışındaki değişkenler (İAÇ, iş doyumu, iş stresi ve ASD) yaşam doyumu varyansın \%24'ünü açıklamaktadır. AIÇ ve ASD dışındaki değişkenler (İAÇ, iş stresi ve yaşam doyumu) ise iş doyumundaki toplam varyansın \%35 ini açıklamaktadır. Yapılan SOBEL aracılık testi ise çatışma ve doyum değişkenleri ilişkisinde iş stresi ve iş doyumunun kısmı aracılık etkisinin bulunduğu, ASD'nin sadece AIÇ ve yaşam doyumu ilişkisine aracılık ettiğini göstermiştir. Bu sonuçlara ilişkin literatürde benzer sonuçların bulunduğu çalışmalar yer almaktadır. Bozoğlan (2014), çatışmanın yordayıcısı olarak sosyal destek ve yaşam doyumu başlıklı çalışmasında test ettiği modelle, sosyal destek ve yaşam doyumunun, çatışmayı \%22 oranında açıkladığını yani sosyal desteğin doğrudan değil yaşam doyumu aracılığ ile çatışma üzerinde daha olumlu bir etkisi olduğu sonucuna ulaşmıştır. Türker ve Çelik (2019) ise çalışmalarında yaşanılan iş-aile çatışmasının, yaşam doyumu üzerindeki etkisinde iş doyumunun aracılık rolü olduğu sonucuna varmışlardır. Atabay ve Naktiyok (2017) çalışmalarında İAÇ ile iş doyumu arasındaki ilişkiyi incelemiş ve bu ilişki de AİÇ nin aracılık etkisine bakmışlardır. Araştırma bulgularına göre, AIÇ üzerinde oluşan negatif yönlü dolaylı etkinin, AIÇ ve iş doyumu arasındaki toplam etkinin belirli bir kısmını oluşturduğunu, bunun yanı sıra AİÇ nin iş doyumu ve İAÇ ilişkisinde önleyici aracılık etkisine sahip olduğunu göstermektedir.

İAYÇ nin da içerisinde yer aldığı tüm rol çatışması türlerinin örgütsel süreçler ve davranışlar üzerinde oldukça önemli etkileri bulunduğu bilinmektedir. Turizm sektöründeki başarı hikayelerinde insan faktörünün çok önemli olduğu göz önüne alındığında, emek yoğun otel işletmelerinin hizmet kalitelerini yüksek standartlarda tutabilmelerinde, çalışanlarının tutum ve davranışları önem arz ettiği bir gerçektir. Dolayısıyla özellikle vardiyalı çalışan departmanlarda, mesai saatlerine düzenleme getirilerek, en yoğun ve stresli geçen vardiya saatleri kısaltılabilir, örgüt psikologları ile iş birliği içerisinde çalışanların stres düzeyleri kontrol altında tutulabilir. Nitekim, Değirmencioğlu ve Öztop 
(2019) havacılık sektöründe yaptıkları çalışmalarında, işgörenlerin iş-yaşam dengesinin, vardiyalı çalışma sistemi ile işten ayrılma niyeti ilişkisi arasında tam aracılık rolü üstlendiği sonucuna varmışlardır. Yine yeni başlayan işgörenler için de örgütsel düzeyde rehberlik ve mentörlük eğitimleri sağlayarak, çalışanların stres faktörlerini minimize ederek aynı zamanda otel içi personel güçlendirme uygulamasına gidilebilir.

Bulgular, İAYÇ düzeyi arttıkça bireylerin yaşam doyumlarının azaldığını açıkça ortaya koyduğundan bu noktada otel işletmelerinin aile dostu bir yaklaşım benimsemelerinin önemi bir kez daha vurgulamaktadır. Byron (2005); Kossek ve Oseki'nin (1998) de belirttiği gibi eşlerin her ikisinin de çalışıyor olmasının aile-iş çatışmasının önemli bir nedenidir. Dolayısıyla çift gelirli çekirdek aile yapısı, çocuğa bakacak aile büyüklerinin/akrabaların olmayışı, bakıcı-kreş sorunları, mesafe ve trafik sebebiyle işe gidiş ve dönüş için harcanan zaman kaybı gibi stres nedenlerinin işe yansıması olasıdır. Bu noktada, otel işletmeleri yöneticilerinin ya da insan kaynakları departmanlarının çocuk sahibi çalışanları için kreş imkânı sağlamalarının aile kaynaklı çatışmaların azalmasına katkı sağlayacağı düşünülmektedir. Özellikle kadın çalışanlarına işgören, eş, anne, evlat, arkadaş, dost, akraba gibi rolleri arasındaki mücadelelerinde pozitif ayrımcılık yapmaları, mesai saatlerini daha kısa belirlemeleri ya da ihtiyaç halinde ve eğer yapılacak iş buna uygunsa ev merkezli çalışma olanağının sağlanması kadın çalışanların işe aidiyet ve bağlllıklarının pekişeceği düşünülmektedir. Arada çalışanlar ve aileleri ile sosyal etkinliklerin düzenlenmesinin hem bireysel hem de örgütsel bağlamda yine olumlu sonuçlar doğurması beklenmektedir. İş görenlerin çalışma arkadaşlarından ve yöneticilerinden alacakları sosyal destek ile birlikte eş, akraba ve dostlarının destekleri ile hatta imkân dahilinde ise ücretli yardımcılardan da destek alınması bireylerin iş ve aile yaşamları arasında denge kurmalarına, dolayısıyla da yaşam doyumlarının artmasına yardımcı olacaktır. Bu dengenin kurulamaması halinde, düşük yaşam doyumu, psikolojik ve fizyolojik sağlık sorunları, evlilik doyumunun azalmasından boşanmalara kadar bireysel problemler doğuracağı gibi, örgütsel açıdan da motivasyon düşüklüğü, verimliliğin azalmasına, örgüt içi personel devir hızının artması gibi pek çok olumsuz sonuç doğurabilecektir. Dolayısıyla insan kaynakları departmanlarının, örgüt içi psikologların, çalışanlar ve ailelerinin bu noktadaki birlikte hareketi ve iş birliğinin önemi çok büyüktür.

İnsan kaynakları departmanlarının, işgörenlerin çatışma ve doyum düzeylerini belirli zaman dilimlerinde analiz etmeleri ve politikalarını bu doğrultuda belirlemeleri gerekmektedir. Personel seçiminde bireyin istihdam edileceği departmana uygunluğu ve adil bir ücretlendirme politikası izlenmesi yine önem arz etmektedir. İş görenlerin yeri geldiğinde yönetsel kararlara katılmasına ve terfi imkanlarına olanak sağlanması iş doyumunu arttıracak unsurlardandır. İş doyumu yüksek işgörenin turizmin her alanında olduğu gibi otel işletmelerinde de hayati öneme sahip olduğu bir gerçektir. İş doyumu yüksek iş görenin müşterilerle olan ilişkisi de daha güler yüzlü, anlayışlı, çözüm odaklı ve sevecen olacağından böyle bir hizmet kalitesi müşteri memnuniyetini beraberinde getirecektir.

Son olarak, yapılan bu araştırmanın bazı sınırlılıkları bulunmaktadır. Uygulamanın İstanbul ve Kuşadası yerleşim yerlerindeki 5 yıldızlı otel işletmelerine belirli bir zaman dilimi ve belirli bir gruba yapılması, ayrıca doyum ve çatışma kavramlarının öznel ve karmaşık yapı sergilemelerinden dolayı, sonuçların bunun bir yansıması olduğu bilinmelidir. Dolayısıyla bundan sonraki araştırmalar, farklı zamanlarda ve daha geniş örneklemler üzerinde uygulanarak, elde edilen sonuçların zamanla daha genellenebilir hale gelmesi mümkündür. Ayrıca her ne kadar araştırmada kullanılan ölçekler, geçerlilik ve güvenirlikleri defalarca test edilerek önceki çalışmalarda kullanılmış olsalar da İAYÇ ve iş doyumu değişkenlerinin ölçme gücü daha yüksek, amaca daha uygun ölçeklerle ölçülebileceği düşünülmektedir. 


\section{KAYNAKÇA}

Adams, G.A., King, L.A. and King, D.W. (1996). Relationships of Job and Family Involment, Family Social Support and Work-Family Conflict with Job and Life Satisfaction, Journal of Applied Psychology, 81(4): 411-420.

Arslan M. (2010). Çalışma Yaşamında Stresin İş Tatmini Üzerindeki Etkisi ve Bir Araştırma, Yüksek Lisans Tezi. Marmara Üniversitesi Sosyal Bilimler Enstitüsü: İstanbul.

Atabay, E.S. ve Naktiyok, A. (2017). İş-Aile Çatışması ile İş Tatmini Arasındaki İlişki ve Bu İlişkide Aileİş Çatışmasının Aracılık Etkisi: Banka Çalışanları Üzerinde Yapılan Bir Araştırma, Küresel İktisat ve İşletme Çalışmaları Dergisi, 6(12):30-45.

Aycan, Z. ve Eskin, M. (2005). Relative Contributions of Childcare, Spousal Support, and Organizational Support in Reducing Work-Family Conflict for Men and Women: The Case of Turkey, Sex Roles, 53(7/8): 453-471.

Benli, A., Yenihan, B. ve Öner, M. (2016). Aile Hekimlerinin İş Tatmin Düzeyleri ile Yaşadıkları İş-Aile Çatışması Seviyeleri Arasındaki İlişki: Kocaeli Örneği, Yönetim Bilimleri Dergisi/Journal of Administrative Sciences, 14(27):415-431.

Bozoğlan, B. (2014). Çatışmanın Yordayıcısı Olarak Sosyal Destek ve Yaşam Doyumu, Kastamonu Eğitim Dergisi, 22(1): 161-175.

Byron, K. (2005). A Meta-Analytic Review of Work-Family Conflict and its Antecedents, Journal of Vocational Behavior, 67: 169-198.

Casper, W.J., Harris, C., Taylor-Bianco, A. and Wayne, J.H. (2011). Work-Family Conflict, Perceived Supervisor Support and Organizational Commitment Among Brazilian Professionals, Journal of Vocational Behavior, 4: 1-13.

Çiftçi, G.E. ve Gürer, Ö. (2018). Mesleki Stres ve Yaşam Doyumu İlişkisinde Psikolojik Güçlendirmenin Aracılık Rolü Üzerine Bir Alan Araştırması, (Tam metin bildiri), Çorum: III. Uluslararası Stratejik Araştırmalar Kongresi, 11-36.

Değirmencioğlu, M. ve Öztop, S. (2019). Vardiyalı Çalışma Sisteminin Çalışanların İşten Ayrılma Niyetine Etkisi Üzerinde İş Yaşam Dengesinin Aracılık Rolü, Mehmet Akif Ersoy Üniversitesi Sosyal Bilimler Enstitüsü Dergisi, 11(29): 623-642.

Deveci, B. (2016). İş-Aile Çatışması ve İş Stresinin Yaşam Kalitesine Etkisi: Büyük Ölçekli Otel Mutfak Çalı̧anları Üzerine Bir Araştırma, Doktora Tezi. Balıkesir Üniversitesi Sosyal Bilimler Enstitüsü: Balıkesir.

Diker, O. (2010). İş-Aile Çatışması ve İşe Bağhllık İlişkisinin Turizm Sektöründe İncelenmesi: Nevşehir Bölgesinde Faaliyet Gösteren Beş Yıldızlı Otel Çalışanları Üzerinde Bir Araştırma, Yüksek Lisans Tezi. Nevşehir: Nevşehir Üniversitesi Sosyal Bilimler Enstitüsü.

Doruk N. Ç. (2008). Organizasyonlarda İş-Aile ve Aile-İş̧ Çatışmalarının Bireylerin Performansları Üzerine Etkisinde İş ve Yaşam Tatmininin Rolü, Yüksek Lisans Tezi. Erciyes Üniversitesi Sosyal Bilimler Enstitüsü: Kayseri 
Dursun, S. ve İştar, E. (2014). Kadın çalışanların Yaşamış Oldukları İş Aile Yaşamı Çatışmasının İş ve Yaşam Doyumu Üzerine Etkisi, Atatürk Üniversitesi İktisadi ve İdari Bilimler Dergisi, 28(3): 127-137.

Efeoğlu, İ.E ve Özgen, H. (2007). İş-Aile Yaşam Çatışmasının İş Stresi, İş Doyumu ve Örgütsel Bağlllık Üzerindeki Etkileri: İlaç Sektöründe Bir Araştırma, Çukurova Üniversitesi Sosyal Bilimler Enstitüsü Dergisi, 16 (2): 237-254.

Erdem, R., Aslan, Ş., Sarı̈üzel, H. ve İşal, D. (2009). Hastane Çalışanlarında İş-Aile Yaşam Çatışması, İş Stresi ve Algılanan Sosyal Destek Arasındaki İlişkilerin Araştırılması, Isparta: Uluslararası Davraz Kongresi, 1442-1454.

Eren, T.A. (2008). Onkoloji Hemşirelerinin İş Doyumu ve Yaşam Doyumunun İncelenmesi, Yüksek Lisans Tezi. Marmara Üniversitesi Sosyal Bilimler Enstitüsü: İstanbul

Frone, M. R., Russell, M., and Cooper, M. L. (1997). Relation of Work-Family Conflict to Health Outcomes: A Four-Year Longitudinal Study of Employed Parents. Journal of Occupational and Organizational Psychology, 70(4): 325-335.

Gutek, B.A., S. Searle and L. Klepa (1991). Rational versus Gender Role Explanations for Work-Family Conflict, Journal of Applied Psychology, 76(4): 560-569.

Grandey, A.A. ve Cropanzano, R. (1999). The Conservation of Resources Model Applied to WorkFamily Conflict and Strain, Journal of Vocational Behavior, 54, 350-370.

Higgins, C. A., and Duxbury, L. E. (1992). Work-family conflict: A comparison of dual-career and traditional-career men. Journal of Organizational Behavior, 13(4): 389-411.

Ilies, R., Wilson, K. S., and Wagner, D. T. (2009). The Spillover of Daily Job Satisfaction onto Employees' Family Lives: The Facilitating Role of Work-Family Integration. Academy of Management Journal, 52(1): 87-102.

Ismail, A. Yao, A. and Yunus, N.K.Y. (2009). Relationship Between Occupational Stress and Job Satisfaction: An Empirical Study in Malaysia, The Romanian Economic Journal, Year XII, 34 (4): 3-29.

Karabacak, G. (2013). İş-Aile Çatışmasının İş ve Yaşam Doyumunda Etkilerinin İş Stresi ve Algılanan Sosyal Destek Açısından Otel Personeli Üzerinde İncelenmesi. (Doktora Tezi) Adnan Menderes Üniversitesi Sosyal Bilimler Enstitüsü, Aydın.

Karabay, M.E. (2015). Sağlık Personelinin İş Stresi, İş- Aile Çatışması ve İş-Aile-Hayat Tatminlerine Yönelik Algılarının İşten Ayrılma Niyeti Üzerindeki Etkilerinin Belirlenmesi Üzerine Bir Araştırma, Yönetim Bilimleri Dergisi, 13 (26): 113-134.

Karakaş, A. ve Şahin, N. (2017). The Relation Between Work Family Life Conflict, Job Performance and Job Stress: A Research on Hotel Employee, Sosyoekonomi, 25(32): 51-69.

Karatepe, O. M. and Baddar, L. (2006). An Empirical Study of the Selected Consequences of Frontline Employees' Work-Family Conflict and Family-Work Conflict, Tourism Management, 27: 1017-1028.

Netemeyer, R.G., Brashear-Alejandro, T. and Boles, J.S (2004). A Cross-National Model of Job-Related Outcomes of Work Role and Family Role Variables: A Retail Sales Context, Journal or the Academy of Marketing Science, 32(1): 4-60. 
Odle-Dusseau, H. N., Britt, T. W., and Bobko, P. (2011). Work-Family Balance, Well-Being, and Organizational Outcomes: Investigating Actual Versus Desired Work/Family Time Discrepancies. Journal of Business and Psychology, 27(3): 331-343.

Öcal, Ö. (2008). İş-Aile Çatışması, İş Tatmini ve Yaşam Tatmini İlişkisini Belirlemeye Yönelik Tekstil İşletmesi Çalışanlarında Bir Araştırma, Yüksek Lisans Tezi, Akdeniz Üniversitesi Sosyal Bilimler Enstitüsü, Antalya.

Özdevecioğlu, M. ve Doruk, N. Ç. (2009). Organizasyonlarda İş-Aile ve Aile-İş Çatışmalarının Çalışanların İş ve Yaşam Tatminleri Üzerindeki Etkisi, Erciyes Üniversitesi İktisadi ve İdari Bilimler Fakültesi Dergisi, 33: 69-99.

Öztürk, N. (2008). Evli Bayan Öğretmenlerde Işs-Aile Çatışmasının İş Stresi ve Performansa Etkileri, Yüksek Lisans Tezi. Yeditepe Üniversitesi Sosyal Bilimler Enstitüsü: İstanbul.

Pluut, H., Ilies, R., Curşeu, P. L., and Liu, Y. (2018). Social Support at Work and at Home: Dual-Buffering Effects in the Work-Family Conflict Process. Organizational Behavior and Human Decision Processes, 146, $1-13$.

Polatçı, S. (2015). Örgütsel ve Sosyal Destek Algılarının Yaşam Tatmini Üzerindeki Etkisi: İş ve Evlilik Tatmininin Aracılık Rolü. Ekonomik ve Sosyal Araştırmalar Dergisi, 11(2): 25-44.

Sayılan, A. A. ve Boğa, S. M. (2018). Hemşirelerin İş Stresi, İş Yükü, İş Kontrolü ve Sosyal Destek Düzeyi ile Tıbbi Hataya Eğilimleri Arasındaki İlişkinin Belirlenmesi, Hemşirelikte Araştırma Geliştirme Dergisi, 20(1): 11-22.

Taşdelen-Karçkay, A., ve Bakalım, O. (2017). The Mediating Effect of Work-Life Balance on the Relationship Between Work-Family Conflict and Life Satisfaction. Australian Journal of Career Development, 26(1): 3-13.

Tekingündüz, S., Kurtuldu, A. ve Öksüz, S. (2015). İş-Aile Yaşam Çatışması, İş Tatmini ve İş Stresi Arasındaki İlişkiler. Siyaset, Ekonomi ve Yönetim Araştırmaları Dergisi, 3 (4): 27-42.

Türker, Y., ve Çelik, K. (2019). Öğretmenlerde İşs ve Aile Çatışmasının Yaşam Doyumu Üzerindeki Etkisinde İş Doyumunun Aracı Rolü. Hacettepe Üniversitesi Ĕğitim Fakültesi Dergisi, 34(1), 242-258.

Üzümcü, T.P. ve Akpulat, N.A. (2017). Turizm İşletmeleri Çalışanlarının İş-Aile Yaşam Çatışması ve Yaşam Doyumları İlişkisi: Kartepe-Çeşme Örneği, Uluslararası Sosyal Araştırmalar Dergisi, 10(51): 10701082.

Yurtseven, Ö. (2008). İş-aile Çatışması, İş Tatmini ve İşten Ayrılma Niyeti İlişkisi: Turizm İşletmesinde Bir Uygulama, Yüksek Lisans Tezi. Akdeniz Üniversitesi Sosyal Bilimler Enstitüsü: Antalya

Wilkin, C.L. (2012). I Can't Get No Job Satisfaction: Meta-Analysis Comparing Permanent and Contingent Workers, Journal of Organizational Behavior, 34 (1): 47-64. 